\title{
NEUROFIBRILLAR DIFFERENTIATION IN 8- TO 14- SOMITES CHICK EMBRYOS
}

\author{
Eros Abrantes Erhart*
}

The beginning of the neurofibrillar differentiation and the development of young neuroblasts in mammals, birds and amphibians attracted the attention of several authors, among them: His ${ }^{8}$, Cajal ${ }^{3}$, Collin ${ }^{4}$, Gerini ${ }^{6}$, Cowdry ${ }^{5}$, Tello ${ }^{10}$, Windle and Austin 11, Angulo y González ${ }^{2}$ and Aboulafia ${ }^{1}$. However, none of them pointed out the presence of fibrillar structure in chick embryos younger than 15 somites. Windle and Austin state: "No trace of neurofibrillar differentiation was observed in chicks smaller than 15 somites but fibrils seem to be forming in 15- and 16- somite specimens.... Our observations on 15- to 18- somite chick embryos agree fairly well with those of Cowdry. This investigator found a few cells of the mid-brain with fibrils at 15 somites".

Our own investigations showed that the neurofibrillar differentiation could be observed in much younger chick embryos, in the rhombencephalic wall of a closing neural tube. Such a differentiation seems to follow definite patterns, since the neuroblasts which first appeared in all the studied chick embryos were restricted to definite areas.

Our thanks are due to Dr. Rita Levi-Montalcini and Dr. Viktor Hamburger for their advice and criticism throughout this investigation.

\section{MATERIAL AND METHOD}

The material used were chick embryos considered normal according to the stage series of Hamburger and Hamilton '. They were impregnated with silver following De Castro's modification of Cajal's method (for details see Levi-Montalcini ${ }^{9}$ ) and studied in transverse serial sections.

As is known, the silver-reduction techniques employed for impregnating embryonic nerve tissue are not uniform concerning the strength of the silver deposition. In our cases the neurofibrillar differentiation could be seen clearly in 23 of the 8-, $10-, 11-, 12-, 13-$ and 14- somite chick embryos that were impregnated; in others, the reaction failed completely or was very light.

To establish the primitive patterns shown by these embryos, a number of older ones were also studied in order to follow the progressive differentiation. The older the embryo, the more constant is the silver reaction.

Trabalho realizado no Departamento de Zoologia da Washington University, St. Louis, Missouri (Prof. V. Hamburger). Apresentado sob forma de Tese de Doutoramento, defendida na Fac. Med. da Univ. de São Paulo em 12 setembro 1956.

* Assistente do Departamento de Anatomia, Secção de Neuranatomia, Fac. Med da Univ. de São Paulo (Prof. O. Machado de Sousa); Fellow da W. K. Kellogg Foundation em 1954-1955. 


\section{OBSERVATIONS}

The youngest embryo in which fibrillogenesis could be observed was an 8- somite embryo. Several neuroblasts (32 in 54 sections) were recognizable by their neurofibrils, which appear as very delicate black-brownish threads, about the nuclei of rounded or spindle-shaped cells located in the lateral neural wall adjacent and just caudal to the otic invagination (figs. 1 and 2 ). The neural tube at this level is still open. Some of the neuroblasts are apolar (according to Angulo y González ${ }^{2}$ ), but the typical bipolar ones are predominant. They are situated at various distances from the ependymal membrane, even in the outer zone. As their axonal process cannot be traced because they are still very short, it is impossible to classify such cells functionally. The other levels of the nervous system did not show cells undergoing neurofibrillar differentiation.

At the 10- and 11- somite stages, the neurofibrillar differentiation showed up as in the 8- somite embryo: it was restricted to the neural tube wall adjacent and just caudal to the incipient otic vesicle. Here, too, the growing axons were very short and did not permit a definite functional classification. However, a comparison with cells in the same location in later stages makes it probable that we are dealing with prospective association or reticular neurons.

At 12 somites, the neurofibrillar differentiation is more evident and the neuroblasts are no longer confined to the region of the otic invagination; a few are also evident at the junction of prosencephalon and mesencephalon (figs. 3 and 4). The general morphology of these cells is the same as that of the rhombencephalic neuroblasts of the 8- somite stage. The rhombencephalic neuroblasts of the 12 - somite embryos, although more numerous at the level of the otic invagination, can be found throughout most of the lateral walls of this brain stem segment. They are situated at various distances from the ependymal membrane and are typically bipolar or unipolar; as the latter (fig. 5) show already growing axons coursing ventrad toward the floor plate, inside the walls of the neural tube, they can be identified as reticular or association neurons.

At 13 and 14 somites the same pattern is observed with an increasing number of differentiating neuroblasts. The ones located in the prosencephalon-mesencephalon junction (figs. 6 and 7), send their axons caudad so as to form what seems to be the primordium of the fasciculus longitudinalis medialis. The rhombencephalic neuroblasts, at this stage, are disposed in three more or less distinct groups: one, cranial to the otic vesicle at the trigeminal level; another, at the otic vesicle level; and a third, at the vagus level. They can be seen either in the basal or alar plates (fig. 8) with growing axons coursing ventrad, craniad or caudad inside the neural walls so as to form the primordia of the association and cordonal systems. Although we were not able to see axons leaving the neural tube, this grouping might indicate a relation of these association neurons to the primordia of the cranial motor nuclei V, VII and vagal complex, which are the first to appear at the end of the second day of incubation. 

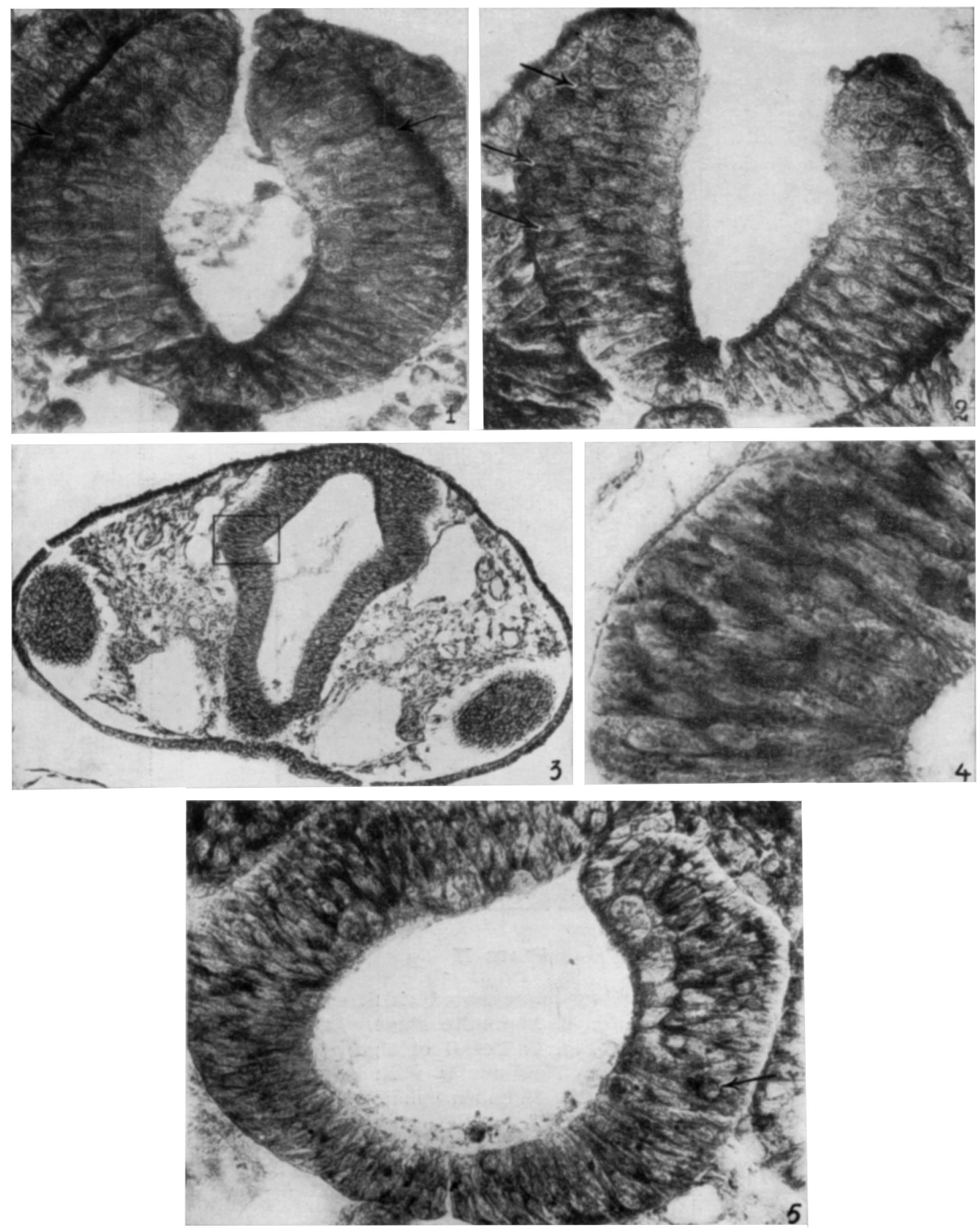

PLATE I

Photomicrographs taken from silver-impregnated chick embryos transverse sectioned $10 \mu$; they were not retuched. Figs. 1 and 2: 8-somite stage. Evident neuroblasts in the still open rhombencephalic neural tube adjacent and just caudal to the otic invagination $(\mathrm{x}$ 1,000). Fig. 3: 12-somite stage. Neurofibrillar differentiation begin. ning to appear at the prosencephalon-mesencephalon junction (x 240). Fig. 4: Detail of figure 3 showing one neuroblast $(x 1,400)$. Fig. 5: 12-somite stage. Unipolar neuroblast at the otic invagination level ( $x 1,000)$. 

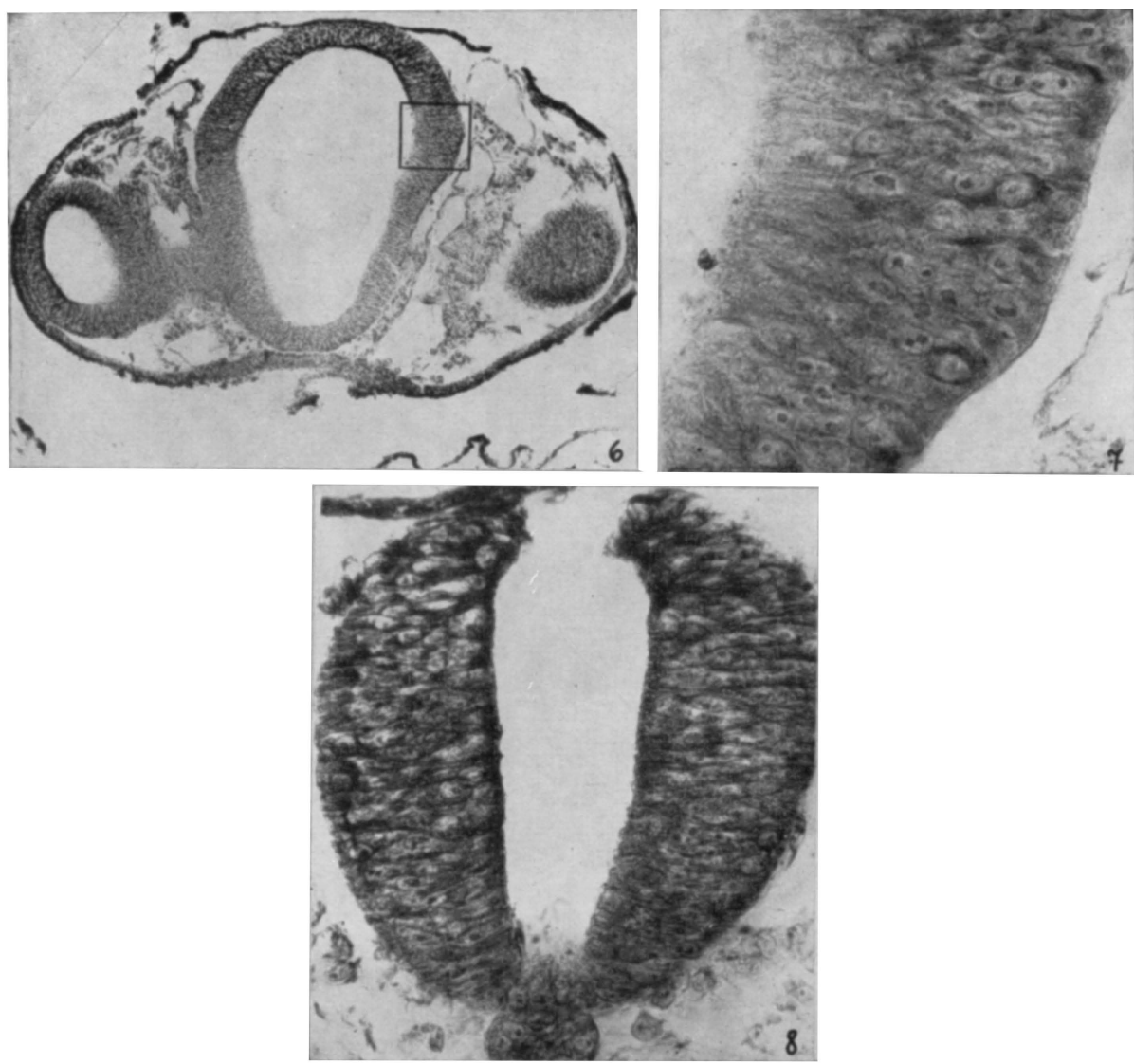

PLATE II

Photomicrographs taken from silver-impregnated chick embryos transverse sectioned $10 \mu$; they were not retuched. Fig. 6: 14-somite stage. Level of the prosencephalonmesencephalon junction $(\times 240)$. Fig. 7 : Detail of figure 6 showing the neuroblasts $(x 1,400)$. Fig. 8: 14-somite stage. Neuroblasts with growing axons in the lateral neural wall of the rhombencephalon $(x 1,000)$.

\section{DISCUSSION AND CONCLUSIONS}

Our knowledge of the first differentiation of neuroblasts is scanty because we have to rely mainly on silver-impregnations. Once a cell exhibits an affinity for silver, we are certain that it has acquired the properties of a neuroblast, but we know that the results of impregnation are not uniform cause we have to rely mainly on silver-impregnations. Once a cell exhibits at the time of fixation may play a role. As information on this topic is still missing, the present investigation was mainly focused on the early appearance of the neurofibrillar differentiation in the chick embryo. 
Concerning the levels of the nervous system and the type of cells with which the differentiation begins, our own results agree with those of Cowdry ${ }^{5}$, Tello ${ }^{10}$ and Windle and Austin ${ }^{11}$, who pointed out that the first neurons to differentiate are association neurons, which appear in the rhombencephalon and at the mesencephalon-prosencephalon junction. Furthermore, Windle and Austin state that prior to the end of the second day of incubation, primary visceral motor neuroblasts are also present and the anlagen of such adult tracts as the medial longitudinal and reticulo-spinal fascicles can be seen. However, we were able to trace the neurofibrillar differentiation to stages much earlier than had been observed before; as can be seen in our 8- somite chick embryo, clearly reacting neuroblasts are already present in the still open rhombencephalic wall.

Another interesting point that could be observed, and as far as we know was not previously mentioned, is the position inside the neural tube of the first neuroblasts to appear, the ones which will become reticular and association neurons. Although they obey patterns of distribution along the main axis, they do not seem to follow a dorso-ventral pattern in the tube; they appear throughout the entire neural wall. This point should be carefully studied in further investigations.

\section{RESUMO}

Com o intuito de estudar o início da diferenciação neurofibrilar dè neuroblastos foram preparados cortes seriados de embriões de galinha impregnados pela prata, modificação de De Castro do método de Cajal.

A diferenciação neurofibrilar inicia-se em fases mais jovens que as descritas na literatura. Em embriões de galinha de 8 somitos, os primeiros neuroblastos são encontrados na região rombencefálica do tubo neural, ainda aberto, na altura da invaginação ótica. Aos 12 somitos, os neuroblastos começam a aparecer, também, na junção prosencéfalo-mesencefálica, e aos 14 somitos, bem mais diferenciados, apresentam evidente, aumento numérico.

Os neuroblastos localizados na junção prosencéfalo-mesencefálica enviam seus axônios caudalmente, constituindo o que parece ser o primórdio do fascículo longitudinal medial. Os neuroblastos rombencefálicos enviam seus axônios ventral-, cranial- e caudalmente, na espessura das paredes neurais, constituindo, provàvelmente, os primórdios dos sistemas cordonais e de associação; por apresentarem-se mais ou menos grupados nos niveis do trigêmio, facial e vago, talvez induzam, também, a pré-organização dos primórdios dos núcleos motores dos nervos V, VII e do complexo vagal.

\section{REFERENCES}

1. ABOUlaFiA, E. D. - On the earliest developmental stages of neurofibrillar genesis. J. Comp. Neurol., 98:531-549, 1953. 2. ANGULO Y GONZALEZ, A. W. Histogenesis of the monopolar neuroblast and the ventral longitudinal path in the albino rat. J. Comp. Neurol., 71:325-360, 1939. 3. CAJAL, S. RAMÓN Y - A quelle époque apparaissent les expansions des cellules nerveuses de la moëlle épinière du 
poulet? Anat. Anz., 5:609-613, 631-639, 1890. 4. COLLIN, R. - Recherches cytologiques sur le développement de la cellule nerveuse. Le Névraxe, 8:185-310, 1906.5. COWDRY, E. V. - The development of the cytoplasmic constituents of the nerve cells of the chick. I: Mitochondria and neurofibrils. Am. J. Anat., 15:389-429, 1914. 6. GERINI, C. - Quelques recherches sur les premières phases de développement des neurofibrilles primitives chez l'embryon du poulet. Anat. Anz., 33:178-189, 1908.7. HAMBURGER, V.; HAMILTON, L. H. - A series of normal stages in the development of the chick embryo. J. Morph., 88:49-92, 1951. 8. HIS, W. - Die Neuroblasten und deren Entstehung im embryonalen Mark. Abh. math. phys. Kl. k. sächs. Ges. Wiss., 15(4), 1889. 9. LEVI-MONTALCINI, R. - The development of the acousticovestibular centers in the chick embryo in the absence of the afferent root fibers and of descending fiber tracts. J. Comp. Neurol., 91:209-242, 1949. 10. TELLO, J. F. Las diferenciaciones neuronales en el embrión de pollo, durante los cuatro primeros dias de la incubación. Tirada aparte del tomo I del Libro en honor de D. Santiago Ramón y Cajal. Madrid, 1922. 11. WINDLE, W. F.; AUSTIN, M. F. - Neurofibrillar development in the central nervous system of chick embryos up to five days' incubation. J. Comp. Neurol., 63:431-463, 1936.

Faculdade de Medicina - Departamento de Anatomia - São Paulo, Brasil. 